\title{
Prevalence and identification of ectoparasites on in- digenous chickens in Seharti-Samre District, Tigray, Northern Ethiopia
}

\author{
Girmay Hiluf, Abrha Bsrat*, Etsay Kebede and Yohannes Hagos \\ College of Veterinary Medicine, Mekelle University, P. O. Box 2084, Mekelle, Ethiopia \\ ${ }^{*}$ Corresponding author: E-mail: abrhish@gmail.com,evermam@yahoo.com
}

\begin{abstract}
A cross sectional study was conducted from February 2014 to February 2015 to estimate the prevalence of ectoparasites and to assess risk factors in indigenous free scavenging chickens in three sub-districts of Seharti-Samre District, northern Ethiopia. Physical examination, hand picking for visible parasites, skin scraping and laboratory based identification of collected parasites were employed on systematically selected 570 indigenous chickens. An overall prevalence of $68.6 \%(391 / 570)$ ectoparasites with a specific prevalence of $44 \%$ (251/570), $14.4 \%(82 / 570)$ and 10.2\% (58/570) for Echidnophaga gallinacea, Argus persicus and mixed infestations, respectively were recorded. Prevalence of $A$. persicus, E. gallinacea and mixed infestation showed statistically significant variation between seasons $(\mathrm{OR}=2.21,95 \%, \mathrm{CI}=1.539-3.178)$, housing in kitchen $(\mathrm{OR}=3.33,95 \%, \mathrm{CI}=2.0228-5.486)$ and main house $(\mathrm{OR}=3.19,95 \%$, $\mathrm{CI}=1.910-5.304)$; age group of birds. The odds of ectoparasites infestation were 3.42 and 7.57 times higher for chick and adults compared with the growers. The current study indicated high prevalence of ectoparasites in backyard poultry management system in the study area. E.gallinacea was found to be the most prevalent ectoparasites identified followed by A. persicus. Designing and implementation of appropriate ectoparasite control measures seems mandatory in order to mitigate economical losses due to ectoparasite infestation.
\end{abstract}

Keywords: Backyard; Ectoparasites; Poultry; Prevalence; Sehart-samre,

\section{Introduction}

Village chicken production has a fundamental role in capital build up, poverty, malnutrition and hunger reduction among the resource poor households in developing countries. Global poultry population has been estimated to be about 16.2 billion, with $71.6 \%$ in developing countries, producing $67,718,544$ metric 
tons of chicken meat and 57,861,747 metric tons of hen eggs (Gueye, 2005). Worldwide, poultry meat and egg production accounts for more than 30\% of all animal protein (Permin and Pedersen, 2000). The International Food Policy Research Institute (IFPRI, 2000) has estimated that by year 2015 poultry accounted for $40 \%$ of all animal protein and they were the available asset to local populations throughout Africa and they contribute to food security, poverty alleviation and promote gender equality, particularly in rural Africa where the majority of the poor people reside. In addition to that village poultry can provide the start of the owner climbing "livestock ladders from small livestock to large livestock species production (Dolberg, 2003). This is because of their good scavenging behaviour, low input requirements for production, short generation intervals, and good adaptation to harsh environments (Besbes, 2009).

In Ethiopia, poultry production is one of the economically important agricultural activities. The recent livestock population estimates that Ethiopia has about 59.50 million poultry of which Tigray region has 5.74 million poultry (CSA, 2017). Ethiopian poultry production systems comprise both traditional and modern production systems, and contribute $98.5 \%$ of the national egg and $99.2 \%$ poultry meat production (Dessie et al., 2002). More than ninety percent of the national poultry population consists of indigenous breed types (Indigenous, 90.85\%; Exotic, 4.39\%; Hybrid, 4.76\%) (CSA, 2017).

Despite their significant roles, poultry have received little attention in almost all the production systems. Their productive performance is disproportional with their size. Although their low performance has masked their potential, the sector boosts the living standards of chicken owners and contributes to rural developments in Ethiopia. The low performance of poultry has been attributed to prevalence of diseases, particularly external parasites (Nyaile et $a l .$, 2003), predators, low genetic potential, limited feed resources, and limited skill in management practices (Sonaiya, 2000; Dana et al., 2010; Yemane et al., 2013 ; Zewdu et al., 2013).

Recently, attempts are underway to enhance the poultry productivity and optimize the contribution of chickens to the national economy despite the negative impact of pathogens. A lot of studies have been conducted on poultry health and their economic and health values. However, most of the studies have focused on viral diseases such as Newcastle disease, infectious bursal disease, fowl pox, avian influenza and Marek's disease among other diseases (Njunga, 2003). The extension messages that were developed on parasites are also mainly focused 
for endoparasites. Ectoparasites have received less attention in most reports and have been considered as side line agricultural activity (Njunga, 2003). Ectoparasites do have an effect on poultry health directly by causing irritation, discomfort, tissue damage, blood loss, toxicities, allergies and dermatitis which in turn alleviate quality and quantities of meat and egg production. They also act as mechanical or biological vectors transmitting number of pathogens (Fabiyi, 1996). Hence, the aims of this study were to estimate the prevalence of ectoparasites, identify the parasitic fauna and the host related risk factors in indigenous free scavenging chickens in the study area.

\section{Materials and methods}

\section{Study area description}

The study was conducted in Seharti-Samre district of south eastern Tigray regional state, Ethiopia. Seharti-Samre is located at $36^{\circ} 27^{\prime} \mathrm{E}$ and $39^{\circ} 59^{\prime} \mathrm{E}$ longitudes, and $12^{\circ} 15^{\prime} \mathrm{N}$ and $14^{\circ} 57^{\prime} \mathrm{N}$ latitudes. The elevation of the district ranges between 1470 and 2370 meters above sea level with mean annual rain fall of 610.5 (351-870) mm (June to August, summer season) and annual average temperature of $22.5^{\circ} \mathrm{C}\left(15-30^{\circ} \mathrm{C}\right)$. The district has a total of 18 sub-districts possessing 65 peasant associations. The population of the district is 151,817 (75,511 male; 76,306 females). In the current study three sub-districts namely, Gijet, Metkel limat and Samre were included purposefully based on the availability of indigenous scavenging poultry population in the study area. The total households of the district are 39,004 (31,083, male headed; 7,921 female headed) among which the study sub-districts possess 4,061 (Metkel limat 1,622, Samre 1,256, Gijet 1,183). The total numbers of poultry in this District are 112,047 among which the study sub-districts posses 17,740 (Samre, 5,265, Giget, 4,627 and Metkel limat 7,848) (Seharti-samre district annual report, 2015).

\section{Study population and sampling procedure}

The study was carried out from February 2014 to February 2015, on a total of 570 chickens managed under backyard production system by collecting data relating with ectoparasitism in the study area. The sample size was determined based on the formula given by Thrusfield (2005) for simple random sampling methods using an expected prevalence of $50 \%$ at $95 \%$ level of confidence and 5\% desired precision. Accordingly, a total of 384 chickens were required 
for this study. However, 570 chickens were systematically selected to increase precision.

Systematic sampling method was applied after sampling interval was determined using the formula $\mathrm{K}=\mathrm{N} / \mathrm{n}$. Where: $\mathrm{N}$ =represents estimated total chickens for backyard farm in sampling frames; $\mathrm{n}=$ represents allocated sample size and $\mathrm{K}=$ interval of household to be sampled (Pfeiffer, 2002). Accordingly, a chick was caught and examined at every 31 household intervals. Chickens of both sexes were included in the study and they were subdivided in to chicks (aged between 1- 3 months), growers (between 3-9 months) and adults (aged greater than 9 months) (Maina, 2005). Age was determined subjectively based on the size of crown, length of spur and flexibility of the xiphoid cartilage (Magwisha et al., 2002).

\section{Collection of ectoparasites and identification}

Ectoparasites were collected, preserved in labeled universal bottles using $70 \%$ alcohol and transported to parasitology laboratory in College of Veterinary Medicine, Mekelle University. Parasites were then identified against their morphological characteristics and entomological keys using light microscope (Soulsby, 1982; Walker, 1994; Wall and Shearer, 1997; Hogsette et al 2003; Taylor et al., 2007; Richman and Koehler, 2007).

\section{Statistical analysis}

Collected data were entered into excel spread sheet of Microsoft office Excel 2010. Individual records and results of the field samples were coded and filled. The data was analysed using SPSS version 17. Descriptive statistics were employed for describing management practices. Logistic regression analysis was conducted to analyze strength of association of odd ratio (OR) at $95 \%$ confidence interval. In all analysis, p-value $<0.05$ was taken as statistical significance value.

\section{Results}

\section{Prevalence of ectoparasites}

An overall prevalence of ecto-parasite infestation of $68.6 \%(391 / 570)$ was recorded in the current study (Table 1). Among the identified parasites, flea 
Echidnophagia gallinacae was found with higher prevalence (44\%) followed by ticks Argus persicus (14.4\%) and mixed infestations of both species (10.2\%).

Table 1. The overall prevalence of ectoparasites in the study area

\begin{tabular}{lccc}
\hline Species of ectoparasites & No. examined & No. infected & Prevalence (\%) \\
\hline E. gallinacae & 570 & 251 & 44.0 \\
A. persicus & 570 & 82 & 14.4 \\
E. gallinacae and A.persicus & 570 & 58 & 10.2 \\
Total & 570 & 391 & 68.6 \\
\hline
\end{tabular}

\section{Distribution of poultry ectoparasites with respect to selected risk factors}

Higher prevalence was recorded from adult and male compared to their counterpart (Table 2). The odds of ectoparasites infestation were $3.42(\mathrm{AOR}=$ 3.42; 95\% $\mathrm{CI}=2.14-5.48)$ and $7.57(\mathrm{AOR}=7.57$; and 95\% $\mathrm{CI}=4.57-11.48)$ higher for chick and adult, respectively compared with the growers. Infestation of birds living on partly isolated house, main house, kitchen and trees were 174/303(57.4\%), 99/122(81.8\%), 108/132(81.1\%) and 10/13(76.6\%), respectively. The risks of acquiring ectoparasites by poultry kept on kitchen and main houses were $3.3(\mathrm{AOR}=3.3 ; 95 \% \mathrm{CI}=2.01-5.49)$ and $3.2(\mathrm{AOR}=3.2,95 \% \mathrm{CI}=1.9$ $5.3)$, respectively times more likely than chicken kept on partly isolated houses. Moreover, significantly higher burden of infestation was recorded in dry season (76.8\%) compared with the rainy season (59.9\%). The risk of acquiring ectoparasites during dry season was 2.21 (OR=2.21 and 95\% CI=1.54-3.1) times more likely than wet season. 
Hiluf et al.,

Table 2. Prevalence of ectoparasites on the basis of age, sex, housing and season

\begin{tabular}{|c|c|c|c|c|}
\hline Variable & No. examined & No. positive (\%) & $\begin{array}{l}\text { Adjusted odd } \\
\text { odd ratio }\end{array}$ & $95 \%$ CI \\
\hline \multicolumn{5}{|l|}{ Age } \\
\hline grower & 151 & $62(41.1 \%)$ & 1 & - \\
\hline chick & 159 & $112(70.4 \%)$ & 3.4 & $2.14-5.48$ \\
\hline adult & 260 & $217(83.5 \%)$ & 7.6 & $4.57-11.48$ \\
\hline \multicolumn{5}{|l|}{ Sex } \\
\hline Male & 159 & $112(70.4 \%)$ & 3.4 & - \\
\hline Female & 151 & $62(41.1 \%)$ & 0.3 & $2.1-5.5$ \\
\hline \multicolumn{5}{|l|}{ Housing } \\
\hline Partly isolated & 303 & $174(57.4 \%)$ & 1 & - \\
\hline kitchen & 132 & $108(81.8 \%)$ & 3.3 & $2.03-5.49$ \\
\hline Main house & 122 & $99(81.1 \%)$ & 3.2 & $1.91-5.30$ \\
\hline Tree & 13 & $10(76.9 \%)$ & 2.5 & $0.67-9.16$ \\
\hline \multicolumn{5}{|l|}{ Season } \\
\hline Wet (Rainy) & 277 & $166(59.9 \%)$ & 1 & - \\
\hline Dry & 293 & $225(76.8 \%)$ & 2.2 & $1.54-3.18$ \\
\hline
\end{tabular}

Prevalence based on ectoparasites species and their site of attachment

In the present study, higher burden of E. gallinacea was found on comb, wattles, and eyelids while higher burden for A. persicus was below the wing (Table $3)$.

Table 3. Prevalence rates of ectoparasites species and their predilection sites

\begin{tabular}{llll}
\hline Attachment site & \multicolumn{4}{l}{ Distribution of ectoparasite Species } \\
\hline Comb & E. gallinacea & A. persicus & Mixed \\
Wattle & $85(14.9 \%)$ & $2(0.4 \%)$ & $3(0.5 \%)$ \\
Comb, wattle \&eye & $98(11.9 \%)$ & $3(0.5 \%)$ & $1(0.2 \%)$ \\
Beneath wing & $1(0.2 \%)$ & $1(0.2 \%)$ & $23(4 \%)$ \\
Comb, Wattle & $6(1.1 \%)$ & $71(12.5 \%)$ & $1(0.2 \%)$ \\
Total & $251(44 \%)$ & $5(0.0 \%)$ & $30(5.3 \%)$ \\
\hline
\end{tabular}




\section{Discussion}

The current study revealed that ectoparasite infestation was a common problem in the study site. The prevalence was found to be higher than previous reports such as 19.3\% in Iraq (Al-Saffar and Al-Mawla, 2008). This variation could be due to difference on husbandry management, housing, community awareness, breed and drug intervention practices.

The prevalence of $E$. gallinacea in the present study was higher than what was previously reported by Mekuria and Gezahegn (2010), 16.5\% in Wolayta Soddo. This discrepancy might be due to the agro-ecological variation of the study sites, community awareness in the different sites, husbandry and feeding system of the poultry production. Furthermore, the current prevalence of $A$. persicus was found to be higher than reports of $9.2 \%$ in Wolayta Soddo town in southern Ethiopia (Mekuria and Gezahegn, 2010) and 6.8\% in Mosul, Iraq (Al-Saffar and Al-Mawla, 2008). Evermore, Swai et al. (2009) reported a very high prevalence $(23.9 \%)$ of $A$. persicus in northern Tanzania. The variation could be due to difference on biosecurity, farming system and status of veterinary service. The most affected sites recorded in the current study were comb, beneath the wings, wattle and eye regions. This might be due to low distribution of feathers, soft and fleshy, and vascular favored for easy invasion by the ectoparasites. This finding was in agreement with the findings of Biu et al (2007) in Nigeria.

A statistically significant difference was observed in the prevalence of ectoparasites between male and female. This disagrees with Sabuni et al (2010) who reported that there was no significant difference in the prevalence rate of ectoparasites infestation between male (37.3\%) and female (34.0\%) in Kenya. This might be due to difference on management system. In the present study, highest prevalence was recorded in chicken kept in main house and kitchen. This might be due to the fact that they shared the ectoparasites from household materials, rodents, animals and humans. With regard to seasonal occurrence of the ectoparasites infestation, high infestation rate was observed in dry season $(76.8 \%)$. This could be due to favorable time for multiplication of the parasites coupled with the limited community awareness to do season based strategic prevention and control approach in the area. 


\section{Conclusion}

The current study indicated high prevalence of ectoparasites in backyard poultry in the study area. E. gallinacea was the most prevalent ectoparasite identified during this study followed by A. persicus. Age, housing condition and season were found to be associated with of external parasites infestation on indigenous chickens in the study area. Control of poultry ectoparasites has received little or no attention from expertise and the community themselves. Hence, strategic control approaches targeting various age groups, type of housing system and season are recommended. Furthermore, detailed studies to investigate the exact economic and public health impact of the existing ectoparasites in the study area could help to develop a sustainable strategy for their prevention and control.

\section{Acknowledgements}

The authors are thankful to Mekelle University College of Veterinary Medicine for allowing their laboratory free of charge during sample processing and parasite identification. Sehart-samre district animal health unit staffs for their technical support and the community for their collaboration during the data collection are also acknowledged.

\section{References}

Al-Saffar, T. M. and Al-Mawla, E. D., 2008. Some hematological changes in chickens infested with Ectoparasites in Mosul, University of Mosul, Iraq. J. Vet. Sci., 22(2), 95-100.

Besbes, B., 2009. Geno-type evaluation and breeding of poultry for performance under sub-optimal village conditions. World Poult. Sci. J., 65, 260-275.

Biu, A. A., Agbede, R. I. and Peace, P., 2007. Studies on ectoparasites of poultry in Maiduguri, Nigeria. Nigerian J. Parasitol., 28, 69-72.

CSA, 2017. Federal Democratic Republic of Ethiopia Central Stastical Agency agricultural sample survey (2016/17 (2009EC)) Vol. II. Statistical, Bulletin No.585. Addis Ababa, Ethiopia.

Dana, N., Van der Waaij, L.H., Dessie, T. and Van Arendonk, J.A., 2010. Production objectives and trait preferences of village poultry producers of Ethiopia: implications 
for designing breeding schemes utilizing indigenous chicken genetic resources. Trop. Anim. Hlth. Prod., 42, 1519-1529.

Dessie, T., Dana, N., Yami, A. and Peters, K.J., 2002. The feed resource base and its potentials for increased poultry production in Ethiopia. World Poult. Sci. J., 58: $77-87$.

Dolberg, F., 2003. Review of Household Poultry Production as a Tool in Poverty Reduction With focus on Bangladesh and India. FAO Pro-Poor Livestock Policy Initiative Working Paper No. 6. Food and Agriculture Organizations of the United Nations. Rome.

Fabiyi, J. P., 1996. Association between duration of humid season and geographical distribution of patterns of different species of chewing lice (Mallophaga: Insecta) infesting domestic chickens in Nigeria. J. Parasitol., 82, 1034-1036.

Gueye, E.F., 2005. Gender aspects in family poultry management systems in developing countries. In: XXII World's Poultry Congress, 8-13 Jan 2004, Istanbul, Turkey. World's Poult. Sci. J., 61, 39-46.

Hogsette, J. A., Jacobs, R.D. and Jacob, J.P., 2003. Common continuous external parasites of poultry. Institute of food and agricultural sciences extension. University of Florida. Fact sheet, PS-10.

IFPRI, 2000. International Food Policy Research Institute: www.cgiar.org/IFPRI. Magwisha, H. B., Kassuku, A. A., Kvysgaard, N.C. and Fermin, A., 2002. A comparison of the prevalence and burdens of helminthes infections in growers and adult free range chickens. Trop. Anim. Hlth. Prod., 34, 205-214.

Maina, A.N., 2005. Prevalence, intensity and lesion associated with gastrointestinal parasites of indigenous chicken in Kenya. MSc thesis, University of Nairobi.

Mekuria, S. and Gezahegn, E., 2010. Prevalence of External parasite of poultry in intensive and backyard chicken farm at Wolayta Soddo town, Southern Ethiopia. Vet. World, 3(12), 533-538.

Njunga, G.R., 2003. Ecto- and haemoparasites of chicken in Malawi with emphasis on the effects of the chicken louse, Menacanthus cornutus. MSc thesis, The Royal Veterinary and Agriculture University, Denmark.

Nyaile, S.F.C., Thekisoe, M.M., Bisschop, S.P. and Mbati, P.A. 2003. A diagnostic survey of avian parasitic infections from village poultry in Qwa-Qwa, South Africa, $J$. Protozool. Res., 13(3-4), 44-50.

Permin, A. and Pedersen G. 2002. Problems related to poultry production at village level. Proceedings of the workshop on the possibilities for Smallholder Poultry Projects in Eastern and Southern Africa. Morogoro, Tanzania, 22-25 May 2000; Pp. 65-69.

Ethiop. Vet. J., 2018, 22 (1), 1-10 
Pfeiffer, D. U., 2000. Veterinary epidemiology-an introduction. The Royal Veterinary College, University of London.

Richman, D. L. and Koehler, P. G., 2007. Fleas: What they are, what they do. Department of Entomology and Nematology, Cooperative Extension Service, Institute of Food and Agricultural Sciences, University of Florida, Gainesville, 32611.

Sabuni, Z.A., Mbuthia P.G., Maingi, N., Nyaga, P.N., Njagi L.W., Bebora L.C. and Michieka J.N., 2010. Prevalence of ectoparasites infestation in indigenous freeranging village chickens in different agro-ecological zones in Kenya. Livestock Res. Rural Dev., 22, 11.

Saulsby, E.J.L., 1982. Helminths, Arthropods and protozoa of Domesticated Animals, $7^{\text {th }}$ ed.

Sonaiya, E. B., 2000. Family poultry and food security: research requirements in science, technology and socioeconomics. Proceedings XXI Word's Poultry Congress, Montreal, Canada, 20-24.

Taylor, M.A., Coop, R.L. and Wall, R.L., 2007. Veterinary parasitology, $3^{\text {rd }}$ ed, Black Wll publishing Ltd. USA, Pp. 522-556.

Thrusfield, M., 2005. Veterinary epidemiology, $3^{\text {rd }}$ ed. Blackwell Science. Ltd. London, UK, Pp. 228-246.

Walker, A., 1994. The arthropods of human and domestic animals. $1^{\text {st }}$ ed, Chapman and Hall, London.

Wall, R.and Shearer, D., 1997. Veterinary entomology. $1^{\text {st }}$ ed, Chapman and Hall, London, Pp. 43-95.

Yemane, N., Tamir,B. and Belihu, K., 2013. Characterization of Village Chicken Production Performance under Scavenging System in Halaba District of Southern Ethiopia. Ethiop. Vet. J., 17 (1), 69-80.

Zewdu, S., Kassa, B., Agza, B. and Alemu, F., 2013. Village Chicken Production Systems in Metekel Zone, Northwest Ethiopia. Wudpecker J. Agri. Res., 2(9), 256-262. 